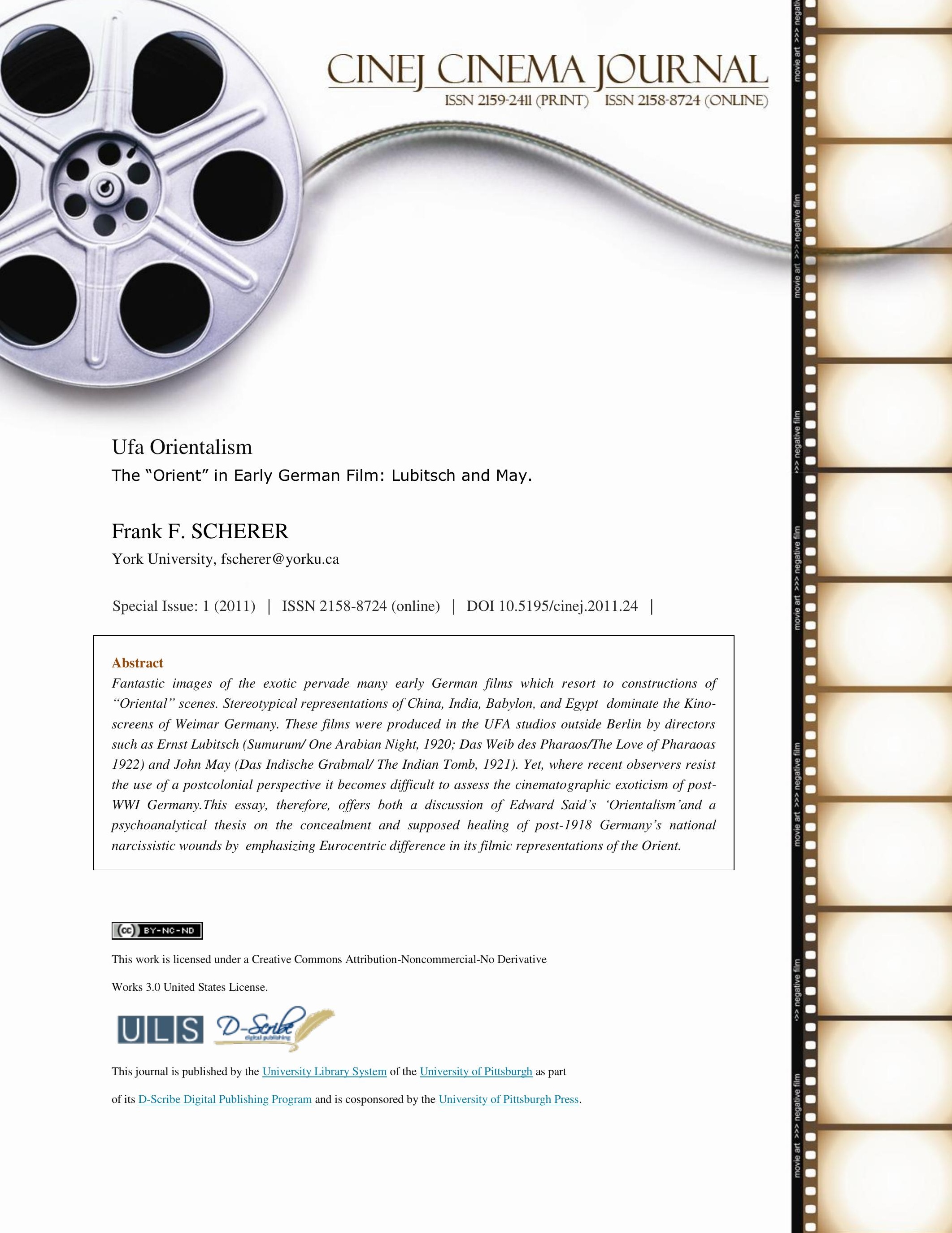




\section{Ufa Orientalism. The "Orient” in Early German Film: Lubitsch and May}

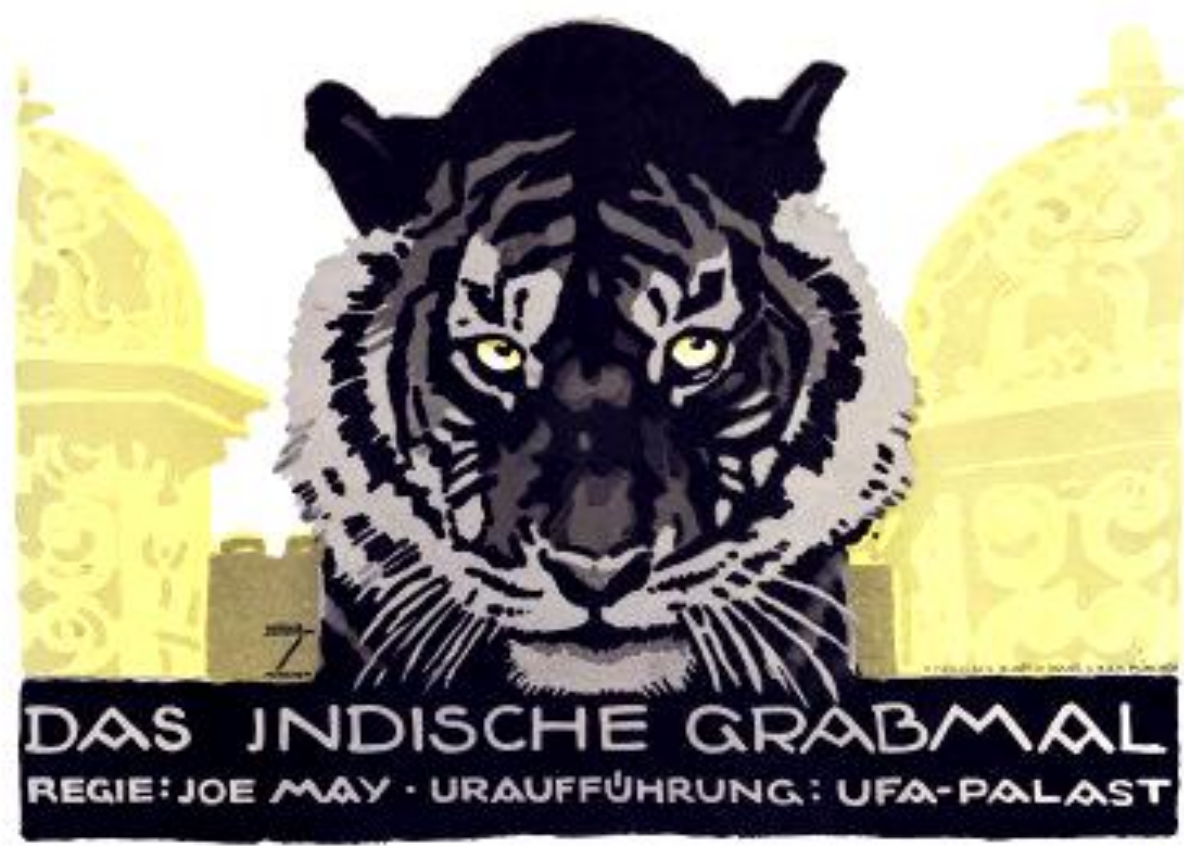

\section{Introduction: German Orientalism and Weimar Cinema}

Fantastic images of Oriental exoticism pervade much of early German film after World War I and into the 1920s, the period commonly known as the Weimar Republic. Be it Ernst Lubitsch's Sumurum/One Arabian Night (1920), his superlative Das Weib des Pharaos/The Loves of Pharoah (1922); or John May's colossal Das Indische Grabmal/ The Indian Tomb (1921); these early German films resort more or less obsessively to constructions of "Oriental" scenes. Largely based on stereotypical representations of India, Babylon, or Egypt and produced in the UFA (Universum Film AG) studios near Berlin, these images dominated the Kino-screens of Weimar Germany. While this filmic German "Orientalism" has been acknowledged by recent commentators such as Richard McCormick, ${ }^{1}$ Christian Rogowski, ${ }^{2}$ and Sabine Hake, ${ }^{3}$ unfortunately, these writers did little more than labeling and nowhere in the literature, old or new, do we find an engaged discussion, let alone an in-depth treatment, of what I will call "UFA Orientalism". My essay will, therefore, explore this recognized - if uncharted - Orientalist terrain in the landscape of early German film and provide the missing postcolonial perspective which, in interdisciplinary mode, will be further strengthened by deconstructionist theory and psychoanalytical insight.

\section{Resisting Orientalism}

Even though the Orientalist leanings of early German film have been noticed by several recent commentators, none has gone beyond mere labeling practices shunning - and thereby resisting - a substantial 
treatment of the Orientalist characteristics of their object of study. Here I want to offer three brief examples. (1) Following Graham Petrie, ${ }^{4}$ Richard W. McCormick divides Lubitsch's costume films into two categories, on the one hand there are the "historical films like Madame DubarryPassion" and, on the other, the "Oriental fantasies like Sumurun/ One Arabian Night." (2) Then there is Sabine Hake's overview of German feature films 19181922 which includes a fleeting remark regarding Lubitsch's "mixture of Jugendstil and orientalism in films like the Mountain Cat and The Love of Pharaoh." (3) Finally, we have Christian Rogowski's article, where the author points out that Joe May's “audience-oriented" fantasy films, and especially Das Indische Grabmal/The Indian Tomb, were "set in the Oriental world of the Middle East."7 If these writers duly acknowledge the Orientalism involved in early German filmmaking, they all resist an in-depth discussion, that is, a sustained reflection of Edward Said's foundational contribution, and thereby a serious consideration of postcolonial theory. Their resistance can perhaps be understood in the context of the theoretical strains of Said's Orientalism. ${ }^{8}$ At this point, I want to propose a twofold strategy and discuss a) the lack of an informed postcolonial critique of early German film and b) the advantages of an interdisciplinary, and in particular psychoanalytical, interpretative take of essentialist cinematographic representations of the Orient during the Weimar period.

By and large, Edward W. Said's Orientalism stands out as a seminal work that, although confronted with harsh criticism, has nonetheless managed for more than three decades to maintain much of its paradigmatic stance. While we can appreciate the significance of its political and intellectual positioning, it has not succeeded in dispelling an array of ontological, epistemological, and methodological short-comings. Orientalism has been perceived both as "forbidding" and "enabling". Forbidding for the monolithic "Occidentalism" that emerges in its pages and enabling for the enormous critical potential his view of "Orientalism" has produced. This enablement is one of the reasons why this book was, and still is, so enthusiastically received by scholars in the social sciences and humanities. And yet, the popular and academic usages that are sometimes made in the name of Said's Orientalism seem uncritical and little aware of a number of contradictions which seriously undermine the authority of this founding contribution to the development of postcolonial theory. While Said's flexible theoretical positioning maybe confounding to some, to others it is precisely this double-sidedness that constitutes the strength of his re-thinking the concept and practice of Orientalism.

However, it is not Said's unfortunate failure to do away with essentialisms of the Occidental and Oriental kinds, but rather his reinforcement of those categories by entrenching them further into his own scheme and, most significantly, his complete oblivion and unreflective erasure of those concerned, the "Orientals", that is at issue here. A closer look at Orientalism and, more precisely, at Said's definitions thereof, will help to explain why the ambiguous and contradictory positioning of his work is of so much importance. It is within the first pages that Said offers no less than four definitions of Orientalism; corporate, academic, stylistic and historical:

a way of coming to terms with the Orient that is based on the Orient's special place in European Western experience. The Orient is not only adjacent to Europe; it is also the place of Europe's greatest and richest and oldest colonies, the source of its civilizations and languages, its cultural contestant, and one of its deepest and most recurring images of the Other. ${ }^{9}$

The Orient is an integral part of Europe an material civilization and culture. Orientalism expresses and represents that part culturally and even ideologically as a mode of discourse with supporting institutions, vocabulary, imagery, doctrines, even colonial bureaucracies and colonial style. ${ }^{10}$ 
Orientalism is a style of thought based upon an ontological and epistemological distinction made between "the Orient" and (most of the time) "the Occident."11

Taking the late eighteenth century as a very roughly defined starting point Orientalism can be discussed and analyzed as the corporate institution for dealing with the Orient - dealing with it by making statements about it, authorizing views of it, describing it, by teaching it, by settling it, ruling over it: in short, Orientalism as a Western style for dominating, restructuring, and having authority over the Orient. ${ }^{12}$

As identified by Ahmad, ${ }^{13}$ we are facing not just pressing ontological as well as epistemological problems, but, moreover, we have an important issue of periodization on our hands. If there is an "uninterrupted" discursive history - as Said, notwithstanding his own arguments, claims on the same pages - that can be traced from Aeschylus to Dante to Marx to Lewis, then the post-Enlightenment eighteenth century can hardly figure as that "roughly defined starting point" of Orientalist discourse. Leaving aside the historical relevance of these questions, they indicate a typical quality of Said's Orientalism which resides in its hybrid positioning. The theoretical and methodological influences apparent in Said's opus magnum are twofold. On the one hand we have his "humanist" claims and, on the other, his use of Foucauldian discourse theory. Having acquired strong formational background in comparative European literatures, Said appears deeply inspired by German comparativists such as Auerbach, Curtius, and Spitzer who were keen on creating an aura of "High Humanism" around their academic endeavors. ${ }^{14}$ The humanist stance reappears in Said's Orientalism in the form of a totalized European history tracing its beginnings - and its Orientalisms - back to Greek classics. This idea was countered in highly critical fashion by the Subaltern Studies Group and several postcolonial thinkers (see Spivak ${ }^{15}$; Bhabha ${ }^{16}$; and Prakash ${ }^{17}$ ). There is, then, the difficulty to reconcile traditional notions of "High Humanism" with poststructural readings of "Nietzschean anti-humanism" as proposed in Foucault's philosophico-historical writings. If James Clifford points to this conceptual weakness, he nonetheless affirms the foundational status of Orientalism by stating that "Said's humanist perspectives do not harmonize with his use of methods derived from Foucault, who is of course a radical critic of humanism. But however wary and inconsistent it's appeals, Orientalism is a pioneering attempt to use Foucault systematically in an extended cultural analysis."18

Another problem is found in the relationship that exists between Orientalism and colonialism. Prioritizing textuality, Said argues that Orientalism "produced" the Orient, ${ }^{19}$ meaning that colonialism is a product of Orientalism itself. Ahmad opposes this view by arguing that this "narrative of convergence between colonial knowledges and colonial powers simply cannot be assembled within cultural studies itself, because histories of economic exploitation, political coercion, and military conquest play the far more constitutive part; those other histories are the ones which provide the enabling conditions for the so-called Orientalist discourse as such." ${ }^{20}$ It is of little help to the theoretical architecture of Orientalism when Said introduces (shortly after corroborating his indebtedness to Foucauldian discourse theory) Gramsci's notion of "hegemony", which pertains to the larger body of Marxist theory. Said thus depends for his conceptual strategy on a highly flexible positionality, constantly vacillating between humanist and anti-humanist paradigms. Still, the point being made here consists not merely in the para-doxical accomplishment of Said's entrenching essentialist distinctions made between the "Occident" and the "Orient", but also in his complete neglect, and thus his erasure, of the subaltern voice. As Aijaz Ahmad remarks: 
A notable feature of Orientalism is that it examines the history of Western textualities about the non-West quite in isolation from how these textualities might have been received, accepted, modified, challenged, overthrown, or reproduced by the intelligentsias of the colonized countries; not as an undifferentiated mass but as situated social agents impelled by our own conflicts, contradictions, distinct social and political locations, of class, gender, region, religious affiliation, and so on - hence a peculiar disjuncture in the architecture of the book." ${ }^{, 1}$

We have not only theoretical and methodological contradictions accompanied by hybrid strategies, but also a fateful obliteration in the silence around those involved - the "Orientals" - which has confronted Said's Orientalism with the devastating charge of "Occidentalism". In other words, Said essentializes Europe and the West, the "Occident", as self-identical, fixed being which has always had an essence and a will, an imagination and a project, and the "Orient" as no more than its silenced object. Accordingly, "Said's discourse analysis does itself not escape the all-inclusive 'Occidentalism' he specifically rejects as an alternative to Orientalism." 22 It is this (reversed) charge of "Occidentalism" which has motivated other writers to go beyond Orientalism and to find alternatives to conceptualize, in the place of silence and neglect, a dialectics involving those concerned. How can we think of Orientalism as an expandable concept, one that takes into account the ways in which it is received, accepted, modified, rejected, or otherwise challenged by the subaltern? Furthermore, how can we conceptualize a critique of Orientalism that includes the subaltern voice? To reach beyond Orientalism means to employ its critical propensities in strategic ways, tapping into its enabling potential which must include the acknowledgment of a plurality of Orientalisms ("proper", "in-reverse", etc.), as well as the conceptual possibilities of an Orientalist dialectics. A number of authors have worked towards a differentiation of Orientalisms, not just in the sense of national histories and conditions, but also in terms of moving away from a one-sided discourse to one of multiplicity and multi-vocality. This is of great significance as such a move makes space for the subaltern voice by opening new terrains of struggle and contestation. This writer fully concurs therefore with Markus Schmitz' conclusion that "the genesis and reception of a critique of Said is of immediate relevance for the question of the $\mathrm{im} /$ possible conditions of cultural de-centering in the tense environment of competing positionalities and unequal representational powers" 23 (my translation). In returning to filmic texts and the apparent resistance of recent commentators to Edward Said's Orientalism, it seems indispensible to measure out the strengths and strains of such an influential work if we are to use postcolonial theory in our exploration of Orientalist representation in Weimar cinema.

\section{Orientalism as Différance and Narcissism}

Ernst Lubitsch's Sumurun/One Arabian Night (1920) clearly exhibits some of the most stereotypical features of western Orientalist representations of historic Babylon such as the Oriental despot, his 1001-like barbarism and especially his cruel mistreatment of women which is accompanied - in classic Freudian key - by the patriarchical/oedipal struggle that ensues between him and his son over the latest addition to his harem. The silent binary that is entrenched here re-proposes the supposed civilizedness of the west as grounded in its liberal democratic superiority. In much the same vein, Joe May's Das Indische Grab/The Indian Tomb (1922) feeds extensively on images of Hindu religion and mysticism, typically projecting Oriental irrationality and timelessness. The other side of the filmic coin once again underlines the secular rationality and progressive modernity of the German viewer. If the Weimar audience may have lost a few rituals and traditions on their forced march into modernity, this Orientalist imagery ideologically reinforces the alleged superiority of an advanced industrialized German Gesellschaft.

CINEJ Cinema Journal: UFA Orientalism . The "Orient" in Early German Film

Special Issue: 1 (2011) | ISSN 2158-8724 (online) | DOI 10.5195/cinej.2011.24 | http://cinej.pitt.edu 
The basic Orientalist binary opposition of Occident versus Orient or west/east evokes a series of other rigid and supposedly stable binary contrasts such as, for example, modern/traditional, civilized/primitive, advanced/backward, rational/irrational, self/ other, male/female, active/passive, colonizer/colonized, and so forth. In structural terms, binary constructs are seen as fundamental organizing elements in human philosophy, language, and culture. ${ }^{24}$ In post-structuralism it is argued that binary oppositions are characteristic of western thought and that, typically, one of the opposites assumes a role of dominance over the other. The critique of binary oppositions has an important place in post-feminist, post-colonial, as well as critical race theory. The post-structural critique of binary constructs consists, however, not simply in a reversal but in their deconstruction. In postcolonial theory this is accomplished by means of introducing a "third term" and, thereby, to undo their apparent stability (see Spivak; Bhabha ${ }^{26}$ ). At the same time, the problematic effectiveness of binary oppositions reaches deeper than may be linguistically apparent.

This problem has been discussed by Jacques Derrida in his Différance ${ }^{27}$ which proposes an insightful reading. He uses the spelling of the French term différance with an $a$ instead of the $e$ as an example/concept and speaks of it as an "infraction in silence", something that is written and read but that cannot be heard. He maintains that it [the $a$ ] cannot be exposed, while indicating "an operation that implies an economical calculation, a detour, a delay, a relay, a reserve, a representation". Its meaning is, therefore, constituted through an act of repression and its sign stands as a "deferred presence" which it aims to re-appropriate. He makes two further points. One rests with the fact that différance with an $a$ is no longer part of the representation of a presence, and secondly, as a result, he questions the very authority of such presence and of its opposite, that is, of lack, or absence. Différance, in Derrida's writing, "maintains our relationship with that which we necessarily misconstrue, and which exceeds the alternative of presence and absence." ${ }^{28}$ The complicated performance of oppositions remains of great importance for a differentiated understanding of so complex a procedure of signification. In this context, Derrida reminds us how "essentially and lawfully, every concept is inscribed in a chain or in a system within which it refers to the other, to other concepts, by means of the systematic play of differences." ${ }^{29}$ Although Derrida's discussion pursues its object still further by probing into the discourses of various influential philosophical precedents it may suffice here to restate that each present element is "related to something other than itself", while being related simultaneously to past and future dimensions, thus "constituting the present by means of this very relation to what it is not." ${ }^{, 30}$ Each Orientalist binary is, thus, a radical displacement, which - within its play of differences - remains intimately tied to its opposite, and beyond, to a history of western (Orientalist) representations.

Already the pioneering German film theorist Siegfried Kracauer had unveiled the essentialist exoticism of Weimar cinema as little more than compensatory gestures by a "cut off", "entrapped" nation after World War I and the Treaty of Versailles. ${ }^{31}$ His early interdisciplinary perspective shows much awareness of the psychoanalytical implications of such filmic displacement into the exotic stopping short of discussing the complexities of collective castration. Similarly, Germany's post-WWI cinematographic Orientalism can be understood in the context of its national/narcissistic wound. In the attempt to bridge psychoanalytical thought and post-colonial theory, which is outlined in more detail elsewhere, ${ }^{32}$ I proposed three doubled conceptual tools: (1) Orientalism Proper or The Narcissism of Eurocentric Difference; (2) Orientalist Binaries or West-Eastern Splitting in the Process of Defense; and (3) Self-Orientalization or Identification with the Imperial Aggressor. Here I will consider mainly the first, that is, German filmic Orientalism of the Weimar period as concealing and supposedly healing a narcissistic wound by way of its emphasis on Eurocentric difference.

The notion "Orientalism proper" is borrowed from John MacKenzie's discussion of Orientalism in history, theory, and the arts ${ }^{33}$ and stands diametrically opposed to Sadik al-Azm's concept of "Orientalism-in- 
Reverse." ${ }^{34}$ If the former corresponds to the orientalization of the Other, the latter implies the orientalization of the Self. It follows Edward Said's original definitions of academic, corporate, and stylistic practices in the process of which the "Orient" and "Oriental" otherness are produced. This process is fundamentally based on Eurocentric views of racial and cultural difference conceived in terms of Occidental superiority and Oriental inferiority. In Said's formulation: "Anyone who teaches, writes about, or researches the Orient - and this applies whether the person is an anthropologist, sociologist, historian, or philologist - either in its specific or its general aspects, is an Orientalist, and what he or she does is Orientalism." ${ }^{35}$ Psycho-analysis allows us to translate Said's foundational postcolonial concept into what Freud, in his Civilization and Its Discontents, coined "the narcissism of minor differences", ${ }^{36}$ meaning the tendency to signal aggression in the encounter with the other. Freud speaks here not only of "Spaniards" and "Portuguese" engaged in constant feuds or simply ridiculing each other. In the context of "Jewish people" he unambiguously reminds us of "all the massacres of Jews" as well as "the dream of a Germanic world-dominion" calling for "antisemitism as its complement." ${ }^{37}$ If the formula "narcissism of minor differences" does not do much to explain it, turning to Freud's work will sharpen the focus.

According to Ernest Jones, Freud used the term "narcissism" for the first time at a Vienna convention in 1909, declaring it to be "a necessary intermediate stage between autoerotism and object-love." writings the concept first appears in a footnote added to the second edition of the Three Essays on the Theory of Sexuality ${ }^{39}$ and, a few years later, in his essay on Leonardo da Vinci. ${ }^{40}$ In both instances the term is used to account for object-choice in homosexuals. Freud's seminal essay "On Narcissism: An Introduction," ["Zur Einführung des Narzissmus"] ${ }^{41}$ brings together several strands of earlier research introducing at same time new concepts with great significance for the development of psychoanalytic theory. In this sense, Freud begins by reiterating Näcke's definition of narcissism as "perversion" and Sadger's note on narcissistic traits in "homosexuals," but, more importantly, by restating Ranke's understanding of narcissism as part of normal or "regular" human sexual development. This last contribution is considerable in that it opens the way to point, away from perversion, to narcissism as "the libidinal complement to the egoism of the instinct of self-preservation, a measure of which may justifiably be attributed to every living creature. ${ }^{, 42}$ Narcissism is thus brought to the discussion in libidinal terms being thought of as a complement to the ego-instinct and as part of a continuum that reaches from pathology ("neurotics") to normalcy ("every living creature"). These considerations eventually prepared the stage for Freud's "extension of the libido theory."

Earlier work with neurotic patients had shown that narcissistic attitudes translate into "limits to their susceptibility to influence," and thus into limits of the psychoanalytic method at large. This finding led Freud to deepen his understanding of narcissism and schizophrenia in the light of libido theory. He continues, therefore, by indicating that schizophrenics display two fundamental characteristics: a) megalomania, which comes into being at the expense of object-libido and b) their marked diversion of interest from the outside world, a process in which "the libido that has been withdrawn from the external world has been directed to the ego and thus gives rise to an attitude which may be called narcissism." ${ }^{43}$ If in the case of schizophrenic patients the libido has truly been withdrawn from the object, in neurotics the process appears to follow a different course. Freud explains that even though the neurotic may have "given up his relation to reality," in contrast to the schizophrenic, "he has by no means broken off his erotic relation to people and things" - he replaces them with others in fantasy. Eventually, Freud is led to "look upon the narcissism which arises through the drawing in of object-cathexes as a secondary one, superimposed upon a primary narcissism that is obscured by a number of different influences." Freud's innovative distinction between primary and secondary narcissism(s) has been praised as "ground-breaking". Paul Ricoeur, for one, conceives of "secondary narcissism" as "a new intelligibility that crowns the attainment of the topo-graphic-economic point of view", foreshadowing "the re-organization of the topography according to the new sequence of ego, id, and superego." ${ }^{44}$ To return to "the narcissism of minor differences" and the disposition of 
aggression toward the other, the withdrawal of libidinal energy from the object onto the ego remains essential to an understanding of the process. So does any insight into Eurocentric views of Occidental self and Oriental other.

The concealing and hoped for healing of Germany's national/narcissistic wound in the aftermath of World War I is thus partly accomplished by recourse to an emphasis on Eurocentric difference in the form of cinematographic Orientalism as exemplified in the films of Lubitsch, May and others. In particular Franz Osten's near-anthropological Die Leuchte Asiens/The Light of Asia (1925) or his Der Wurf des Schicksals/The Throw of Dice (1927) would merit extended analysis. However, Osten's films are not discussed here as they demand separate treatment having been initiated by Indian producers, financed by Indian investors, and shoot on location in India (see Ascárate ${ }^{45}$ ). Another aspect of importance in the production of early German Orientalist films which cannot be treated here is found in the involvement of both Lubitsch and May with Hollywood and the USfinanced, German-based film company EFA (see Horak ${ }^{46}$ and Drössler ${ }^{47}$ ).

\section{Conclusion: Narcissism, Eurocentrism, and Orientalism}

This article has discussed the recurrent Orientalist imagery in early German film of the Weimar period by considering two contexts. On the one hand, we noted the lack of an informed postcolonial critique among recent writers and have, therefore, provided a sustained analysis of Edward Said's foundational text. On the other hand, in view of the ontological, etymological, and methodological shortcomings of Said's Orientalism we have offered an interdisciplinary - and in particular psychoanalytical - interpretation of Germany's national/narcissistic wound in the aftermath of WWI as being concealed and supposedly healed by way of emphasis on Eurocentric difference (read superiority) in its essentialist representations of the Orient.

1 R. McCormick, "Sex, History and Upward Mobility: Ernst Lubitsch's Madame Dubarry/Passion" in German Studies Review, Vol. 33, Nr. 5, October 2010, pp. 603-617.

2 C. Rogowski, "Movies, Money, and Mystique: Joe May's Early Blockbuster, The Indian Tomb (1921)" in N. Isenberg (ed.), Weimar Cinema. The Essential Guide to Classic Films of the Era. New York: Columbia University Press, 2009.

${ }^{3}$ S. Hake, Passions and Deceptions. The Early Films of Ernst Lubitsch. Princeton: Princeton University Press, 1992.

${ }^{4}$ G. Petrie, Hollywood Destinies: European Directors in Hollywood. 1922-1931. London: Routledge and Kegan Paul, 1985.

${ }^{5}$ R. McCormick, 2010, p. 604.

${ }^{6}$ S. Hake, 1992, p. 37.

${ }^{7}$ C. Rogowski, 2009, p. 62.

${ }^{8}$ E. Said, Orientalism. New York: Vintage Books/A Division of Random House, 1979. 
${ }^{9}$ E. Said, 1979, p. 1.

${ }^{10}$ E. Said, 1979, p.1-2.

${ }^{11}$ E. Said, 1979, p. 2.

12 E. Said, 1979, p. 3.

${ }^{13}$ A. Ahmad, In Theory. Classes, Nations, Literatures. London and New York: Verso, 1994, p. 180.

${ }^{14}$ A. Ahmad, 1994, p. 162.

15 G.C. Spivak, "Subaltern Studies. Deconstructing Historiography" in D. Landry and G. Maclean (eds.), The Spivak Reader. London and New York: Routledge, 1996.

${ }^{16}$ H.K. Bhabha, The Location of Culture. London and New York: Routledge, 1994.

${ }^{17}$ G. Prakash, "Writing Post-Orientalist Histories of the Third World: Perspectives from Indian Historiography" in Comparative Studies in Society and History 32, 1990, p. 2.

18 J. Clifford, The Predicament of Culture. Twentieth-Century Ethnography, Literature, \& Art. Cambridge: Harvard University Press, 1988, p. 264.

${ }^{19}$ E. Said, 1979, p. 3.

${ }^{20}$ A. Ahmad, 1994, p. 164.

${ }^{21}$ A. Ahmad, 1994, p. 172.

22 J. Clifford, 1988, p. 271.

${ }^{23}$ M. Schmitz, Kulturkritik ohne Zentrum. Edward W. Said und die Kontrapunkte kritischer Dekolonisation. Bielefeld: transcript verlag, 2008, p. 363.

${ }^{24}$ S. Hall, (ed.) Representation. Cultural Representations and Signifying Practices. London, Thousand Oaks, New Dehli: Sage Publications, 1997, pp. 234-238.

${ }^{25}$ G.C. Spivak, 1996.

${ }^{26}$ H.K. Bhabha, 1994.

27 J. Derrida, "Différance" in Margins of Philosophy. Translated with notes by A. Bass. Chicago: The University of Chicago Press, 1982.

28 J. Derrida, 1982, p. 20.

29 J. Derrida, 1982, p. 11.

30 J. Derrida, 1982, p. 13.

${ }^{31}$ S. Kracauer, From Caligary to Hitler. A Psychological History of German Film. Princeton: Princeton university Press, 1947, p. 23. 
${ }^{32}$ F. Scherer, Freud's Orient. Early Psychoanalysis, "Anti-Semitic Challenge", and the Vicissitudes of Orientalist Discourse. Unpublished Dissertation, York University, Toronto, 2010.

33 J.M. MacKenzie, Orientalism. History, theory and the arts. Manchester and New York: Manchester University Press, 1995, p.26.

${ }^{34}$ S.J. al-'Azm, "Orientalism and Orientalism in Reverse" in Khamsin Nr. 8, (1981), p. 5.

${ }^{35}$ E. Said, 1979, p. 2.

${ }^{36}$ S. Freud, "Civilization and its Discontents" in Standard Edition Vol. XXI. Translated from the German by James Strachey. London: The Hogarth Press, 1981 [1930], pp. 114-115.

${ }^{37}$ S. Freud, 1981 [1930], p. 116.

${ }^{38}$ E. Jones, The Life and Work of Sigmund Freud. New York: Basic Books, 1981, p.304.

${ }^{39}$ S. Freud, "Three Essays on the Theory of Sexuality" in Standard Edition VII. Translated from the German by James Strachey. London: The Hogarth Press, 1981 [1905].

40 S. Freud, "Leonardo Da Vinci and a Memory of His Childhood" in Standard Edition XI. Translated from the German by James Strachey. London: The Hogarth Press, 1981 [1910].

${ }^{41}$ S. Freud, "On Narcissism: An Introduction" in Standard Edition Vol. XIV. Translated from the German by James Strachey. London: The Hogarth Press, 1981 [1914].

42 S. Freud, 1981 [1914], p. 74.

${ }^{43}$ S. Freud, 1981 [1914], p. 75.

${ }^{44}$ P. Ricoeur, Freud and Philosophy. An Essay on Interpretation. New Haven: Yale University Press, 1970, p. 127.

${ }^{45}$ R.v. Ascárate, "Cinematic Enlightenment: Franz Osten's Die Leuchte Asiens (1925)" in Quarterly Review of Film and Video, Vol. 25, pp. 357-367, 2008.

46 J.-C. Horak, "Rin-Tin-Tin in Berlin or American cinema in Weimar" in Film History, Vol. 5, pp. 49-62, 1993.

${ }^{47}$ S. Drössler, "Ernst Lubitsch and EFA" in Film History, Vol. 21, Nr. 1, pp. 208-228, 2009.

Frank F. SCHERER (PHD) teaches Social Science in the Department of Human Rights and Equity Studies at York University, Toronto/ Canada. He is author of "Freuds Morgenland. OrientalisTick und die Entstehung der Psychoanalyse" in Rüdiger Görner and Nima Mina (Hrsg.) "Wenn die Rosenhimmel tanzen ..." Oriental Motifs in $19^{\text {th }}$ and $20^{\text {th }}$ Century German Literature. München: Iudicium Verlag (2006); "Oriental(ist) Scenes. Orientalism of Psychoana-analysis/Psychoanalysis of Orientalism" in S. Movahedi, M. Tamgidi, J. Capetillo-Ponce, G. Jacobs (eds.) The Discourse of Sociological Practice, Vol. 7, Issues 1\&2, Spring/Fall (2005); "Sanfancón: Orientalism, Self-Orientalization, and 'Chinese Religion' in Cuba" in Patrick Taylor (ed.), Nation Dance: Religion, Identity and Cultural Difference in the Caribbean. Bloomington: Indiana University Press 2001. 